\title{
Signaling of vitamin D receptor, 1 alpha-hydroxylase and RANTES genes in dairy cows with hypocalcaemia
}

\author{
Hala A. R. Saed ${ }^{1}$, and Hussam M. M. Ibrahim²* \\ ${ }^{1}$ Veterinary Teaching Hospital, Faculty of Veterinary Medicine, Mansoura University, Mansoura, Egypt \\ ${ }^{2}$ Department of Internal Medicine, Infectious and Fish Diseases, Faculty of Veterinary Medicine, Mansoura \\ University, Mansoura, Egypt
}

SAED, H. A. R., H. M. M. IBRAHIM: Signaling of vitamin D receptor, 1 alpha-hydroxylase and RANTES
genes in dairy cows with hypocalcaemia. Vet. arhiv $91,575-588,2021$.

ABSTRACT

The aim of the current study focused on screening the signal of the vitamin D receptor (VDR), 1-alpha-hydroxylase ( $1 \alpha$-OHase) enzyme, and chemokine regulated on activation, normal T-cell expressed and secreted (RANTES) genes in dairy cows with hypocalcaemia. A sample of 120 dairy cows (20 dairy cows per herd) in the transition period was studied. Blood samples were drawn from the selected dairy cows for both biochemical and molecular analysis. In cows with subclinical and clinical hypocalcemia, there was a significant $(\mathrm{P}<0.05)$ down-regulation of both VDR and RANTES genes, whereas there was a significant $(\mathrm{P}<0.05)$ up-regulation of the $1 \alpha$-OHase enzyme. Moreover, there was a significant $(\mathrm{P}<0.05)$ increase in the levels of glucose, parathyroid hormone $(\mathrm{PTH})$, sodium $(\mathrm{Na})$, and chloride $(\mathrm{Cl})$. Furthermore, there was a significant $(\mathrm{P}<0.05)$ decrease in the levels of phosphorous and potassium $(\mathrm{K})$. On the animal level, there was a significant association between the expression pattern of the VDR gene and the cows' breed, the cows' age, parity number, body condition score, and history of previous transition period disorders. The increase in both the expression of $1 \alpha$-OHase enzyme and the level of each of PTH, glucose, $\mathrm{Na}$, and $\mathrm{Cl}$ in the serum were significant risk factors for the decreased expression of the VDR gene. Likewise, the decrease in both the expression of the RANTES gene and the level of calcium $(\mathrm{Ca})$ and phosphorous in the serum were significant risk factors for decreased expression of the VDR gene. This study revealed that the expression of VDR, $1 \alpha$-OHase enzyme, and RANTES genes in the blood was greatly affected in dairy cows with hypocalcemia, indicating the need for an extra dose of vitamin $\mathrm{D}$ to maintain the normal level of $\mathrm{Ca}$ in the blood, especially during periods of high need. Hence, this study provides an insight into the role of vitamin D and its related enzymes in promoting the productivity of dairy cows, especially during the critical production periods.

Key words: vitamin D receptor; 1- $\alpha$ hydroxylase enzyme; RANTES; hypocalcemia; dairy cow

\section{Introduction}

The transition period in dairy cows is the most challenging and critical period in relation to their health status during the lactation cycle. There are many inter-related physiological, nutritional, metabolic, and immunological disturbances that

dairy cows encounter at the onset of milk secretion, concomitantly with parturition, which are a constant concern for dairy producers, nutritionists, and veterinarians (GROSS et al., 2011).

\footnotetext{
*Corresponding author:

Hussam Mohamed Ibrahim, Department of Internal Medicine and Infectious Diseases, Faculty of Veterinary Medicine, Mansoura University, Mansoura 35516, Egypt, Phone: +2 0502214 233; +2 01005290 592; E-mail: hussam-habosha@mans.edu.eg
} 
Hypocalcaemia, a term applied to cows whose blood calcium (Ca) level is $<2.0 \mathrm{mmol} / \mathrm{L}$, is a rather unique endocrine disorder that has major negative implications for the profitability of dairy production systems all over the world (DEGARIS and LEAN, 2008; CONSTABLE et al., 2017). The onset of lactation induces more significant changes in the Ca metabolism compared to the changes that occur at parturition, which contribute to hypocalcemia, as the loss of $\mathrm{Ca}$ from the blood to milk may exceed 50 gram per day (DEGARIS and LEAN, 2008). Hypocalcemia is a common metabolic disorder in dairy cows, with incidence reaching up to $83 \%$ on the herd level, leading to increased prevalence of various other transition period disorders, increased risk of detrimental health and production outcomes, and threatened life in severe cases (LEAN et al., 2006). Therefore, cows with milk fever are eight times more likely to develop mastitis in the subsequent lactation, are three times more likely to develop dystocia, and are two to four times more likely to develop displaced abomasum (MULLIGAN et al., 2006).

Vitamin D is recognized as a prohormone that is widely known to be primarily involved in the mechanism of $\mathrm{Ca}$ homeostasis. The active form of vitamin D, 1,25- dihydroxyvitamin D3 $\left(1,25(\mathrm{OH})_{2} \mathrm{D}_{3}\right)$, is formed by hydroxylation of 25-hydroxyvitamin $\mathrm{D}$ in the kidneys, with the help of the 1-alpha-hydroxylase ( $1 \alpha$-OHase) enzyme, thus mediating $\mathrm{Ca}$ homeostasis by the aid of the parathyroid hormone $(\mathrm{PTH})$. The $1,25(\mathrm{OH})_{2} \mathrm{D}_{3}$ binds to its receptor protein, known as the vitamin $\mathrm{D}$ receptor(VDR), and they form a molecular complex responsible for up and down-regulation of several genes, whose function is impeded in regulation of Ca homeostasis (DELUCA, 2004; WILKENS and MUSCHER-BANSE, 2020). When the plasma Ca level drops, the PTH is released, which raises the expression of the $1 \alpha$-OHase enzyme to produce $1,25(\mathrm{OH})_{2} \mathrm{D}_{3}$ that stimulates the absorption of $\mathrm{Ca}$ from the intestine, as well as its reabsorption by the kidneys (HORST et al., 2003; ÖZÇELIK et al., 2017).

In milk production systems, Ca-related metabolic disorders are frequent, and may be associated with a deficiency in the intake of vitamin supplements, especially vitamin D. As noted, the biological activity of vitamin $\mathrm{D}$ is carried out by the activation of the VDR by $1,25(\mathrm{OH})_{2} \mathrm{D}_{3}$. Moreover, the $\mathrm{Ca}$ binding and transport genes in the intestine and kidneys, and consequently blood $\mathrm{Ca}$, are influenced by the concentration of $1,25(\mathrm{OH})_{2} \mathrm{D}_{3}$ circulating in the blood. The concentration of $1,25(\mathrm{OH})_{2} \mathrm{D}_{3}$ in blood is primarily determined by the expression of the $1 \alpha-\mathrm{OHase}$ enzyme that is tightly regulated in response to the PTH and $1,25(\mathrm{OH})_{2} \mathrm{D}_{3}$ at a ratio that keeps $1,25(\mathrm{OH})_{2} \mathrm{D}_{3}$ circulating at a concentration that maintains the level of $\mathrm{Ca}$ in the blood (HAUSSLER et al., 2013). To date there are plentiful data related to the valuable role of VDR in Ca homeostasis in humans (NELSON et al., 2010) and in Holstein dairy cows (ALI et al., 2018; SAED et al., 2020). Accordingly, our hypothesis was that understanding the changes that occur in the VDR gene expression during the transition period in dairy cows with hypocalcemia can help to predict these health problems during this critical period. Thus, the purpose of the current study focused on screening the expression of the VDR, $1 \alpha$-OHase enzyme, and chemokine regulated on activation, normal T-cell expressed and secreted (RANTES) genes in dairy cows with hypocalcemia. Moreover, it addressed the association between the risk factors that play a significant role in the transition period and the suspected changes in the expression profile of the VDR gene in dairy cows with hypocalcemia.

\section{Materials and methods}

Study population. A case-control study was conducted on the basis of an appropriate sample of six different farms of dairy cattle from Dakahlia and Damietta governorates in Egypt, between January 2019 and December 2019. The inclusion criteria for herds were (1) a semi-open shaded pen housing system with at least 100 milking cows, (2) feeding on an NRC based diet, (3) periodical monitoring using a metabolic profile test, and (4) computerized herd management software. The average herd size was 260, and ranged from 150 to 400 lactating cows. The average milk production was $6,500 \mathrm{~kg}$ and ranged from 4,000 to $10,000 \mathrm{~kg}$. A sample size of 120 dairy cows (20 dairy cows per herd) in the transition period was studied. Three breeds were represented, as follows: foreign breed [Holstein $(\mathrm{n}=39)$ and Friesian $(\mathrm{n}=29)]$, and mixed native 
breed $(\mathrm{n}=52)$. Their ages ranged between 2.3 and 9.6 years, and their weight ranged between 280 and $600 \mathrm{~kg}$. This investigation was permitted by the Animal Welfare and Research Ethics Committee, Faculty of Veterinary Medicine, Mansoura University, Mansoura, Egypt, code No. R/27.

Clinical examination. A case report form for each cow was obtained by direct inquiry from the responsible veterinarians and herd managers at each visit, to document the case history, time of calving, calving ease, and clinical symptoms of hypocalcemia. Cows were assumed to suffer hypocalcemia on the basis of symptomology, and this was further confirmed by the analyzing the serum $\mathrm{Ca}$ level, as previously stated by CONSTABLE et al. (2017). The studied dairy cows with subclinical hypocalcemia did not show any clinical symptoms. However, dairy cows with clinical hypocalcemia showed anorexia, some initial excitement, tremors in the muscles of the head and limbs, ear twitching, staggering, and recumbency. They took up the sternal recumbent position, often tucking their heads into their flanks. Then they appeared to be dull, with a dry muzzle, staring eyes, cold legs and ears, lower than normal body temperature, tachycardia, weakened heart contractions and peripheral pulse, and were unable to urinate or defecate. Untreated cows with hypocalcemia took a lateral recumbent position with muscle flaccidity, and were unresponsive to stimuli, lost consciousness, which progressed to coma and death. To identify the possible risk factors related to dairy cows with hypocalcaemia and their impact on the expression profile of the VDR gene, all the required data were collected using questionnaires constructed with only closed questions. The data related to the possible animal level risk factors were obtained for each cow studied, including breed, age, parity number, body condition score, stage of transition period, and history of previous transition period disorders. The criteria within each obtained item were given scores for further statistical analysis.

Definition of hypocalcemia on individual cow level. When the Ca level in the blood was greater or equal to $2.1 \mathrm{mmol} / \mathrm{L}$, the cows were recorded as normocalcemic. Meanwhile, when the serum $\mathrm{Ca}$ level in the examined dairy cows ranged between
1.5 and $2.0 \mathrm{mmol} / \mathrm{L}$, and the cows were not affected clinically, they were recorded as cows with subclinical hypocalcemia. However, dairy cows showed clinical signs of hypocalcemia with a serum Ca level below $1.5 \mathrm{mmol} / \mathrm{L}$, and they were recorded as cows with clinical hypocalcemia (COOK et al., 2006; REINHARDT et al., 2011; WILHELM et al., 2017). On the basis of both thorough clinical examination and the blood Ca level results of the sampled dairy cows per farm, the studied dairy cows were categorized as normocalcemic ( 40 cows with normal serum Ca level; $\geq 2.1 \mathrm{mmol} / \mathrm{L}$ ), subclinical hypocalcemia (55 cows with serum Ca level 1.5 $2.0 \mathrm{mmol} / \mathrm{L}$ ), and clinical hypocalcemia (25 cows with serum Ca level below $1.5 \mathrm{mmol} / \mathrm{L}$ ).

Blood sampling. By puncturing the jugular vein, two samples of peripheral blood, 5 mLeach, were drawn from each cow under investigation. For molecular analysis, the first blood sample was drawn in a vacuum blood collection tube with ethylenediaminetetraacetic acid (EDTA) (EDTA K3 Tube, Golden Vac, China). Meanwhile, for biochemical analysis, the second blood sample was drawn in a plain vacuum collection tube (Golden Vac, China), which was left undisturbed at room temperature for 30 minutes to allow it to clot. The clot was removed and the serum was separated by centrifuging the collected samples, at $1568 \mathrm{~g}$ for 10 minutes at room temperature in a centrifuge (Hettich EBA 8S centrifuge, Leszno, Poland). The collected samples of both serum and whole blood were aliquoted, numbered, and kept frozen at -80 ${ }^{\circ} \mathrm{C}$ until analyzed.

Molecular analysis. RNA was extracted from the whole blood samples and the cDNA was synthetized according to the method previously described by SAED et al. (2020). Quantitative real-time PCR was used to assess the expression pattern of the VDR, $1 \alpha$-OHase enzyme, and chemokine RANTES genes. The expression pattern of the VDR gene was evaluated using the following primers set, with accession No.\#NM_001167932: the forward strand, 5'- AGCCACCGGCTTCCATTTCA -3', and the reverse strand, 5'- AACAGCGCCTTCCGCTTCAT -3' (NELSON et al., 2010). The expression pattern of the $1 \alpha$-OHase enzyme gene was assessed using the following primers set, with 
accession No. \# XM_588481: the forward strand, 5'- TGGGACCAGATGTTTGCATTCGC -3 ', and the reverse strand, 5'TCTCAGACTGGTTCCTCATGGCT (AALBERTS et al., 2007). The expression pattern of the chemokine RANTES gene was examined using the following primers set, with accession No. \# NM_175827: the forward strand, 5'- CACCCACGTCCAGGAGTATT -3', and the reverse strand, 5'- CTCGCACCCACTTCTTCTCT -3' (NELSON et al., 2010). For all studied genes, optimized PCR reaction conditions and amplification were implemented according to the program described by SAED et al. (2020).

The relative expression of the assessed genes in cows with normal $\mathrm{Ca}$ level was used as a control value to quantitatively assess the fold change variation in their expression pattern in the diseased cows, relative to this control value. Besides, the mRNA transcripts were relatively quantified and specified using the $2^{-\Delta \Delta \mathrm{Ct}}$ method (LIVAK and SCHMITTGEN, 2001), where the house keeping gene was the $\beta$ - actin gene, with accession No. \# NM_173979.3. The sequence of the used primers set for the $\beta$ - actin gene was: the forward strand, 5'- GGCATCCTGACCCTCAAGTA -3', and the reverse strand, 5'-CACACGGAGCTCGTTGTAGA -3' (NELSON et al., 2010).

Biochemical analysis. The serum glucose level was colorimetrically measured using Spinreact kits (SPINREACT, S.A., Girona, Spain). However, the serum level of PTH was quantitatively determined following the standard method using a bovine PTH ELISA test kit (MyBioSource Inc., San Diego, CA, USA). Meanwhile, the assessment of the levels of $\mathrm{Ca}$, phosphorous, magnesium $(\mathrm{Mg})$, potassium $(\mathrm{K})$, sodium $(\mathrm{Na})$, and chloride $(\mathrm{Cl})$ in the serum was performed using a spectrophotometer with commercial test kits (Human Gesellschaft Fur Biochemica und Diagnostica mbH, Germany). All the selected parameters were biochemically analyzed in the serum samples using the detection methodology described by their manufacturers.

Statistical analysis. Data analysis was performed using a statistical software program (SPSS for Windows, Version 21.0, SPSS Inc., USA). To test the normal distribution of the data, the Kolmogorov-Smirnov test was selected, which indicated that the data were normally distributed, hence the values of each biochemical variable were presented as mean and standard deviation (SD). The data were subjected to One Way Anova with post hoc Dunn multiple comparison tests to assess the statistical differences between groups. The cutoff point of each biochemical parameter was analyzed using the ROC curve analysis. Univariate analysis using a Chi-square test was used to assess the association between the expression of the VDR gene and the suggested risk factors on both the individual animal level and the serum biochemical parameters level. The P-value, odds ratio (OR), and a 95\% confidence interval (CI 95\%) were recorded for each variable. In all statistical analyses, the results were considered to be significant at $\mathrm{P}<0.05$.

\section{Results}

On the basis of both the clinical signs reported in the studied dairy cows and the Ca threshold of 2.1 $\mathrm{mmol} / \mathrm{L}$, the prevalence of subclinical hypocalcemia and clinical hypocalcemia was $45.8 \%(55 / 120)$ and $20.8 \%(25 / 120)$, respectively. None of the studied dairy cows with subclinical hypocalcemia showed any clinical symptoms. However, in those with clinical hypocalcemia the following clinical symptoms were recorded: anorexia in $23 / 25$ cows (92\%), some initial excitement in $20 / 25$ cows $(80 \%)$, tremors in the muscles of the head and limbs in $3 / 25$ cows $(12 \%)$, staggering and incoordination in $3 / 25$ cows $(12 \%)$, sternal recumbency in $18 / 25$ cows $(72 \%)$, inability to stand in $15 / 25$ cows $(60 \%)$, and lateral recumbency with cold extremities in $2 / 25$ cows $(8 \%)$. In the recumbent dairy cows, a dry muzzle, cold legs and ears, constipation and lethargy were also recorded. Moreover, the body temperature fell below the normal range, and the heart beat became weaker and faster.

In cows with subclinical and clinical hypocalcemia, the expression of the VDR and RANTES genes was significantly down-regulated $(\mathrm{P}<0.05)$, whereas the expression of the $1 \alpha$-OHase enzyme was significantly up-regulated $(\mathrm{P}<0.05)$ in comparison with those with a normal Ca level. Furthermore, there was a significant difference in the expression of the VDR, $1 \alpha$-OHase enzyme and RANTES genes between dairy cows with 
clinical hypocalcemia and those with subclinical hypocalcemia. In cows with clinical hypocalcemia, there was a significant $(\mathrm{P}<0.05)$ increase in the glucose level, while, there was a significant $(\mathrm{P}<0.05)$ decrease in the phosphorous level when compared to those with a normal $\mathrm{Ca}$ level and those with subclinical hypocalcemia. However, the PTH level had increased greatly $(\mathrm{P}<0.05)$ in dairy cows with subclinical and clinical hypocalcemia compared to those with a normal Ca level (Table 1). There were non-significant changes in the level of $\mathrm{Mg}$ in the studied dairy cows with subclinical and clinical hypocalcemia when compared with those with a normal $\mathrm{Ca}$ level. However, the levels of $\mathrm{K}$, $\mathrm{Na}$, and $\mathrm{Cl}$ were significantly $(\mathrm{P}<0.05)$ increased in cows with clinical hypocalcemia compared to those with subclinical hypocalcemia and those with normal Ca levels (Table 2).

On the animal level, all the studied dairy cows with subclinical and clinical hypocalcaemia (n $=80$ ) showed decreased expression of the VDR gene. Thus, the distribution of risk factors and the univariate analysis of the decreased expression pattern of the VDR gene are presented in Table 3. There was a significant association between breed and expression pattern of the VDR gene, where 52 dairy cows of foreign breed (Holstein and Friesian) $(65 \%)$ with hypocalcemia expressed downregulation of this gene $(\mathrm{P}=0.009$; OR: $0.359 ; 95 \%$ CI: $0.164-0.785)$. The cows' age had a significant association with the expression pattern of the VDR gene, where 52 hypocalcemic dairy cows $(65 \%)$ expressing down-regulation of this gene were older than 5 years $(\mathrm{P}=0.004$; OR: 0.206 ; $95 \%$ CI: 0.067 - 0.639). Likewise, parity number was a significant factor in the VDR gene expression pattern, where 68 dairy cows with hypocalcemia $(85 \%)$ with a parity number $>3$ times showed a decreased expression of the gene $(\mathrm{P}=0.002$; OR: 3.778; 95\% CI: 1.565 9.120). Similarly, the body condition score had a significant association with the expression pattern of the VDR gene, where 52 hypocalcemic dairy cows $(65 \%)$ with a body condition score $\geq 3.5$ had decreased expression of the VDR gene $(\mathrm{P}=0.009$; OR: 2.786 ; 95\% CI: 1.275 - 6.088). Furthermore, dairy cows that had suffered from previous transition period disorders were more likely to have a decreased expression of the VDR gene, where 48 dairy cows with hypocalcemia (60\%) with previous transition period disorders showed a decreased expression of the VDR gene ( $\mathrm{P}=0.001$; OR: 0.167; 95\% CI: 0.068 - 0.408).

On the basis of the cutoff point of the investigated serum parameters, the distribution of the serum parameters as risk factors and the univariate analysis of the decreased VDR gene expression are presented in Table 4. Both the increase in $1 \alpha$-OHase enzyme expression and the decrease in RANTES expression were significant $(\mathrm{P}<0.05)$ risk factors for the decreased expression of the VDR gene. All the 80 studied dairy cows with hypocalcemia $(100 \%)$ expressed up-regulation of $1 \alpha$-OHase enzyme and down-regulation of the chemokine RANTES gene. In cows with hypocalcemia, the decreased serum level of both $\mathrm{Ca}$ or phosphorous was a significant risk factor for the decreased expression of VDR gene. All the 80 studied dairy cows with hypocalcemia $(100 \%)$, with a low Ca level $(<2.1$ $\mathrm{mmol} / \mathrm{L}$ ), expressed down-regulation of the VDR gene $(\mathrm{P}<0.05)$. Furthermore, 56 dairy cows out of 80 hypocalcemic dairy cows $(70 \%)$ showed a significant decrease in the level of phosphorous $(<1.60$ $\mathrm{mmol} / \mathrm{L}$ ), with a decreased expression of the VDR gene $(\mathrm{P}=0.002$; OR: 3.50; 95\% CI: 1.584 - 7.735).

The increased serum level of glucose, PTH, $\mathrm{K}, \mathrm{Na}$, or $\mathrm{Cl}$ was a significant risk factor for the decreased expression of the VDR gene. Out of 80 dairy cows with hypocalcemia, 64 dairy cows (80\%) showed a significant increase in the level of glucose $(>2.62 \mathrm{mmol} / \mathrm{L}$ ) with down-regulation of the VDR gene ( $\mathrm{P}=0.001$; OR: 0.063; 95\% CI: 0.024 - 0.161). Moreover, 72 dairy cows (90\%) showed a significant increase in the level of PTH $(\geq 42.63 \mathrm{pg} / \mathrm{mL})$, with a decreased expression of the VDR gene $(\mathrm{P}=0.001$; OR: 0.028 ; 95\% CI: $0.010-0.081)$. Likewise, 52 dairy cows $(65 \%)$ showed a significant increase in the $\mathrm{K}$ level $(\geq 4.25 \mathrm{mmol} / \mathrm{L})$, with a decreased expression of the VDR gene ( $\mathrm{P}=0.009$; OR: 2.786; $95 \%$ CI: 1.275 - 6.088). Furthermore, 56 dairy cows $(70 \%)$ showed a significant increase in $\mathrm{Na}$ level and 52 dairy cows $(65 \%)$ showed a significant increase in $\mathrm{Cl}$ level, with a decreased expression of the VDR gene $(\mathrm{P}=0.001$; OR: 0.107 ; 95\% CI: $0.043-0.266)$ and $(\mathrm{P}=0.002$; OR: 0.290; 95\% CI: $0.131-0.643)$, respectively. 

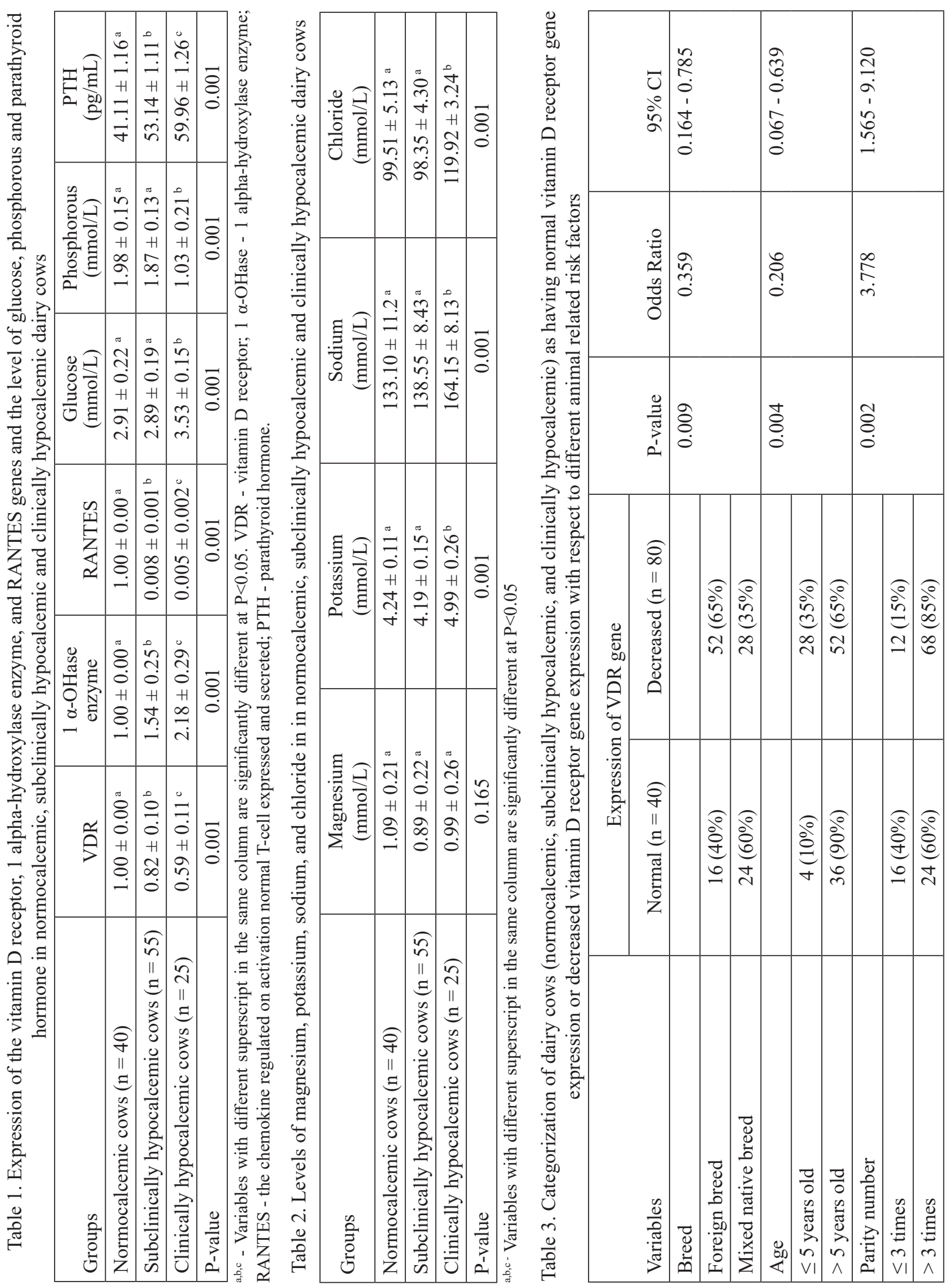
H. Saed and H. Ibrahim: Vitamin D receptor, 1- $\alpha$ hydroxylase enzyme, and RANTES genes expression in hypocalcemic dairy cows
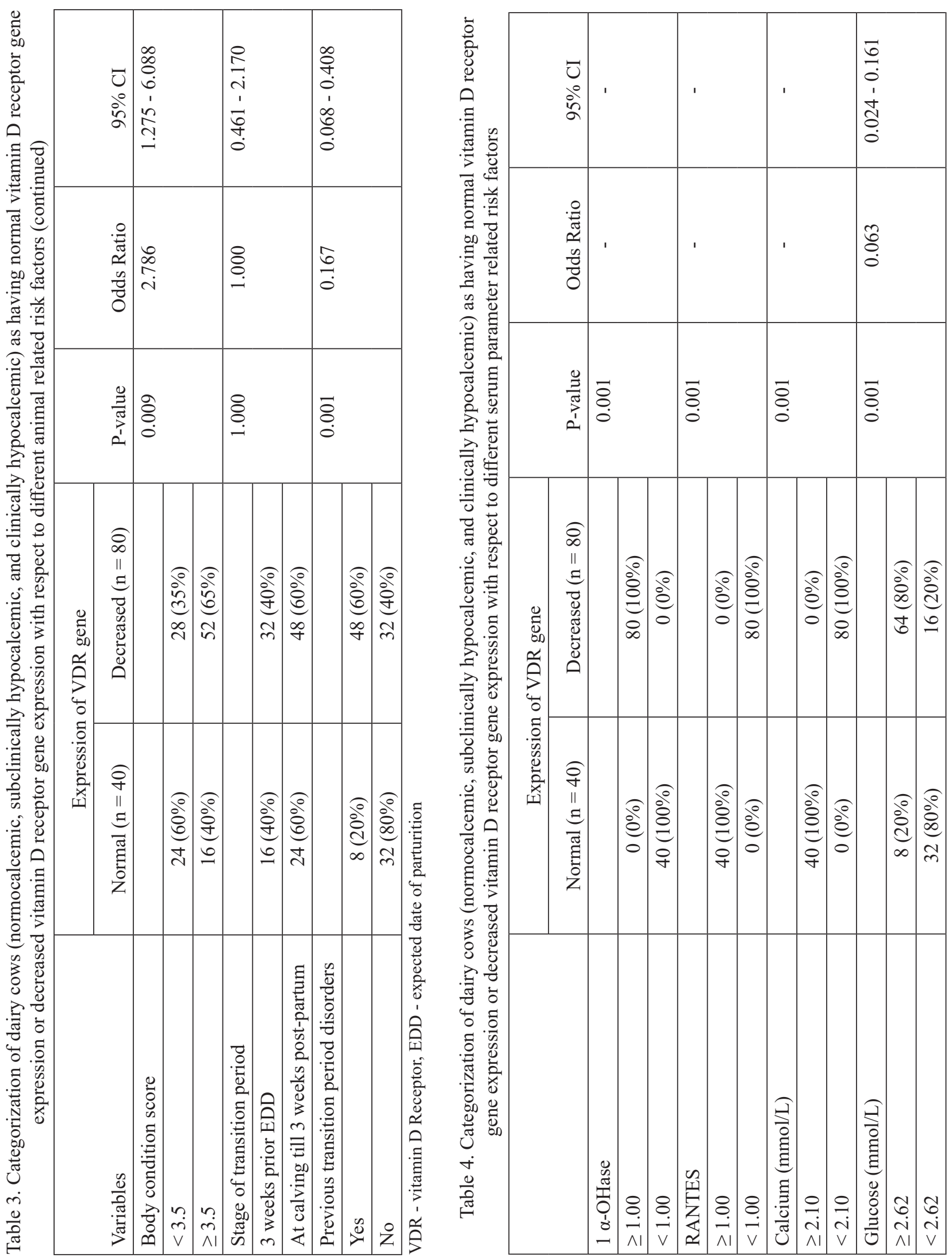


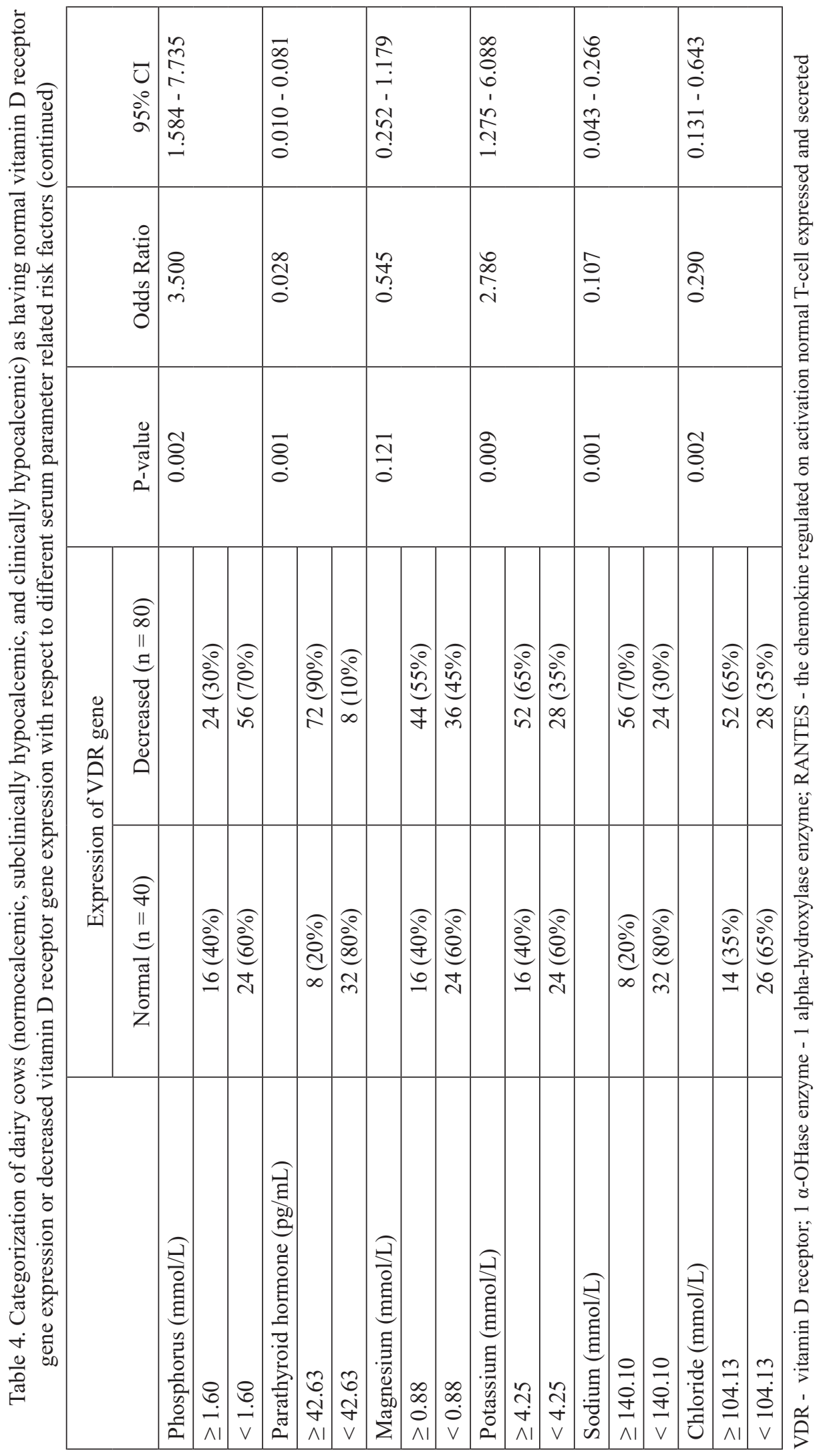




\section{Discussion}

Vitamin D is an integral component of $\mathrm{Ca}$ homeostasis in both animals and humans. The molecular mechanism of this biological process is very sophisticated, and includes a large amount of up and down-regulation of various genes. There is a large amount of data regarding the VDR and $1 \alpha$-OHase enzyme gene profile in human diseases, but this topic is still somewhat unexplored in bovine medicine, where hypocalcemia in dairy cows is widespread, especially during transition period. This is the first study to demonstrate the expression pattern of the VDR, $1 \alpha$-OHase enzyme and RANTES genes in dairy cows with hypocalcaemia, with special reference to their relationship to some serum parameters that play a crucial role in the occurrence of this metabolic disorder.

The severity of the clinical signs depends on how low the level of $\mathrm{Ca}$ in the blood is, however, signs may become worse when the levels of both glucose and other minerals and tissue elements, including phosphorous, $\mathrm{Mg}, \mathrm{K}$, and $\mathrm{Na}$ are changed. In the current study, the levels of $\mathrm{Ca}$, glucose, phosphorous, $\mathrm{Mg}, \mathrm{K}, \mathrm{Na}$, and $\mathrm{Cl}$ were not altered greatly in the cows with subclinical hypocalcemia, and therefore these cows did not express any detectable clinical signs. In contrast, all of these analyses were significantly altered in the cows with clinical hypocalcemia, particularly $\mathrm{Ca}$ and phosphorous levels, and were mainly responsible for the clinical signs recorded, as previously reported by GOFF (2008); TADESSE and BELETE (2015); CONSTABLE et al. (2017). The failure of a cow to maintain the normal serum $\mathrm{Ca}$ level during the transition period is due to the failure to adapt its mineral metabolism properly in response to higher $\mathrm{Ca}$ requirements. Dairy cows require about 20 gram of $\mathrm{Ca}$ per day at the end of the dry period, while, when colostrum is produced, their requirements rise to $30-70$ grams per day, depending on the amount of daily milk production. The natural homeostatic mechanism that is able to regulate the level of $\mathrm{Ca}$ in plasma with remarkable precision takes approximately 48 hours, which may result in Ca deficiency in this critical period (GOFF, 2008; KUREK et al., 2016).

With respect to the gene expression profile, the current study revealed the relative down-regulation of the VDR gene during episodes of hypocalcaemia in the studied dairy cows, which may be considered a cause of the condition rather than a consequence. HORST et al. (2003) stated that even if $1,25(\mathrm{OH})_{2} \mathrm{D}_{3}$ reaches its highest level by up-regulation of the $1 \alpha$-OHase gene, its mission will be disturbed in the case of a lack of VDR protein. In a study conducted on sheep and goats, there was increased demand for $\mathrm{Ca}$ during gestation and lactation, which was met by the mobilization of $\mathrm{Ca}$ from the bones, and an increase in its absorption from the intestine. Vitamin D has the main influence on this physiological process of active absorption, which works through the VDR present in the mucosal wall of the intestine, thereby increasing the absorption of $\mathrm{Ca}$. As a result of the pronounced effect of pregnancy and lactation on the VDR, Ca absorption is inadequate with the resultant metabolic diseases such as milk fever (LIESEGANG et al., 2007). The issue needs further study to reveal how the expression profile is modified in dairy cows with hypocalcaemia that recovered.

In the studied dairy cows with hypocalcemia, the up-regulated profile of the $1 \alpha$-OHase enzyme gene was noticed. In sheep and goats fed a diet deficient in $\mathrm{Ca}$, there is increased secretion of PTH, with the consequent stimulation of renal $1 \alpha$-OHase enzyme expression in both monogastric species (BECKMAN et al., 1995), and female sheep and goats (HERM et al., 2015; WILKENS et al., 2018). The expression of the $1 \alpha$-OHase enzyme is negatively associated with $1,25(\mathrm{OH})_{2} \mathrm{D}_{3}$ in the form of a negative feedback mechanism, with a major share in the PTH (SUNG et al., 2012). The high level of $1,25(\mathrm{OH})_{2} \mathrm{D}_{3}$ is offset by high production of the VDR protein, so that there is up-regulation in the expression profile of the gene and vice versa. NAVEH-MANY et al. (1990) showed that physiologically relevant doses of $1,25(\mathrm{OH})_{2} \mathrm{D}_{3}$ in rats resulted in an increase in VDR mRNA level in the parathyroid glands, with a decrease in PTH mRNA level. PTH is necessary for up-regulation of $1 \alpha$-OHase enzyme gene expression. Hence, vitamin $\mathrm{D}_{3}$ deficiency is accompanied by deficiency of the VDR protein, and thus down-regulation of the VDR gene takes place, along with the up-regulation of the $1 \alpha$-OHase enzyme gene, to activate vitamin $D_{3}$.

In hypocalcemic dairy cows, the downregulation of the chemokine RANTES gene 
occurs in line with the down-regulation of the VDR gene, and a positive correlation between these two genes was previously recorded in an in-vitro study (NELSON et al., 2010). A study conducted by KLEIN et al. (2016) demonstrated that cultured peripheral blood mononuclear cells produce the chemokine RANTES in proportion to the medium Ca level, strengthening the hypothesis of the positive correlation between the Ca level and expression pattern of the chemokine RANTES.

The level of glucose increased significantly in the studied dairy cows with clinical hypocalcemia compared to those recorded in cows with subclinical hypocalcemia and cows with a normal Ca level. In Holstein dairy cows, HERNÁNDEZCASTELLANO et al. (2017) observed a decrease in the insulin concentration during the postpartum period, which is usually related to the onset of lactation, resulting in an increase in the blood glucose level. Likewise, in-vitro studies on $\beta$ cells in various animal species and humans have shown that pancreatic cells require $\mathrm{Ca}$ influx into the cytosol in order to release insulin granules and to respond to insulin after glucose tolerance tests (RORSMAN et al., 2012). Thus, hypocalcemia impairs insulin production and release in dairy cows with milk fever, which in turn leads to an increase in glucose level in their blood by reducing peripheral tissue glucose uptake (HAYIRLI, 2006). Furthermore, in a study conducted to evaluate chemical profiles in cows within 12 hours of calving, LARSEN et al. (2001) reported a negative correlation between the level of glucose and the level of $\mathrm{Ca}$ in the blood. Moreover, in Holstein dairy cows, SAED et al. (2020) revealed that there was a positive association between the level of $\mathrm{Ca}$ and the expression pattern of the VDR gene during the transition period. This clarifies the significant association between the expression pattern of the VDR gene and the level of glucose in hypocalcemic dairy cows.

Previous studies indicated that the changes in plasma phosphorous level are parallel with the plasma $\mathrm{Ca}$ level as parturition approaches, confirming the results showing the phosphorous level in the studied cows with clinical hypocalcemia. The decreased phosphorous level in the studied dairy cows with clinical hypocalcemia may be attributed to the increased PTH level, with resultant increased renal excretion of phosphorous by reducing tubular reabsorption through internalization of the sodiumdependent phosphate $\left(\mathrm{Na}-\mathrm{P}_{\mathrm{i}}\right)$ co-transporters, thus increasing urinary phosphorous concentration (BERNDT et al., 2005; BERNDT et al., 2007). It also stimulates active phosphorous secretion in the salivary glands, which reaches the rumen, but it cannot be readily utilized (WRIGHT et al., 1984). Furthermore, CONSTABLE et al. (2017) debated whether the decreased phosphorous level that occurs in cows with milk fever is the result of hypocalcemia and recumbency rather than a concurrent event. Since the serum Ca level is positively associated with the serum phosphorous level, and the serum $\mathrm{Ca}$ level is positively correlated with the VDR gene expression, a significant association was documented between the VDR gene expression pattern and the phosphorous level in dairy cows with hypocalcemia.

In the studied dairy cows with subclinical and clinical hypocalcemia, the PTH level increased significantly when compared with those with a normal $\mathrm{Ca}$ level. When cows develop a hypocalcemic state, they respond rapidly by increasing secretion of $\mathrm{PTH}$, which activates the $\mathrm{Ca}$ homeostatic mechanisms, including renal re-absorption of urinary $\mathrm{Ca}$, osteoclastic bone resorption, and increased renal production of the hormonal form of vitamin $\mathrm{D}$ in order to enhance intestinal absorption of dietary Ca (LIESEGANG et al., 1998; HERNÁNDEZ-CASTELLANO et al., 2017, ÖZÇELIK et al., 2017). The PTH suppresses VDR gene expression as the serum PTH is inversely proportional to the serum $\mathrm{Ca}$ level, and the PTH has a blocking action on a $1,25(\mathrm{OH})_{2} \mathrm{D}_{3}$-mediated increase in the renal VDR (HEALY et al., 2005). This explains the significant association recorded between the expression pattern of the VDR gene and the PTH level in hypocalcemic dairy cows.

In the studied dairy cows with clinical hypocalcemia, the $\mathrm{K}$ level in the blood was inversely correlated with the $\mathrm{Ca}$ level, and was therefore accompanied by mild hyperkalemia synchronized with metabolic acidosis, that usually occurs during this time. The dairy cows appeared to be highly susceptible to sub-acute rumen acidosis during the early lactation period, which may be due to the instability of the rumen microbial population that 
always occurs when the balance between lactateproducing bacteria and lactate-utilizing bacteria is disrupted (DEVRIES et al., 2009; RÉRAT et al. 2009). The acidosis and the high glucose level in the blood work together to cause fluid and $\mathrm{K}$ to move out from the cells into the bloodstream. Likewise, patients with an increased level of glucose often have diminished kidney capacity to excrete $\mathrm{K}$ into the urine. Therefore, the combination of both the $\mathrm{K}$ shifting out from the cells into the blood circulation and the diminished urine $\mathrm{K}$ excretion causes hyperkalemia (UDENSI and TCHOUNWOU, 2017). Thus, there is a significant association between the expression pattern of the VDR gene and the level of $\mathrm{K}$ in the studied hypocalcemic cows. This association can be attributed to the negative association between the level of $\mathrm{Ca}$ and the level of $\mathrm{K}$ in the blood, and the positive association between the level of $\mathrm{Ca}$ and the expression pattern of the VDR gene, as previously reported in Holstein dairy cows during the transition period (SAED et al., 2020).

A decrease in the Ca level in the bloodstream, as well as an increase in the PTH level is mostly associated with increased activity of the renninangiotensin-aldosterone system, which leads to a positive $\mathrm{Na}$ and $\mathrm{Cl}$ balance, with an increase in the extracellular fluid volume. Likewise, an increase in the Na level during this critical period may be associated with an increase in the concentration of aldosterone, which is usually observed during the first week of lactation (SKRZYPCZAK et al., 2014). Hypernatremia and hyperosmolarity in animals and humans are associated with impairment of both the insulin-mediated glucose metabolism and glucagon-dependent glucose release. Hence, hypernatremia is often associated with hypocalcemia, hyperglycemia, and endocrine dysfunction (LIAMIS et al., 2014). On the basis of both the positive association between the level of $\mathrm{Ca}$ and the expression pattern of the VDR gene, and the negative association between the level of $\mathrm{Ca}$ and the level of $\mathrm{Na}$, a significant negative association was reported between the expression pattern of the VDR gene and the level of both $\mathrm{Na}$ and $\mathrm{Cl}$ in dairy cows with hypocalcemia.

Regarding the investigated risk factors, the cows' breed had the greatest impact on the expression of the VDR gene. Foreign breed (Holstein and Friesian) with hypocalcemia was significantly associated with decreased expression of the VDR gene. Genetically, the high-producing foreign breeds lose more $\mathrm{Ca}$ in their milk, making them more susceptible to this condition (LEAN et al., 2006; ROCHE and BERRY, 2006; SABORÍOMONTERO et al., 2017). Thus, these breeds endure hypocalcaemia with a concurrent down-regulation of the VDR gene. In Egypt, Holstein and Friesian cows are known for their higher milk production compared to the native breeds, and hence a high percentage of $\mathrm{Ca}$ is pooled to the mammary glands.

The incidence of hypocalcaemia is often increased in multiparous and elderly cows, starting from the $3^{\text {rd }}$ lactation onwards, due to increased $\mathrm{Ca}$ mobilization from their bone reserves to cope with milk production, especially with impaired absorption of $\mathrm{Ca}$ by the intestinal cells (SAED et al., 2020a). Furthermore, the intestinal VDR count decreases with increasing age, resulting in a decrease in the response of intestinal cells to $1,25(\mathrm{OH})_{2} \mathrm{D}_{3}$ (HORST et al., 1990). Accordingly, the increase in both age and parity time of the studied dairy cows had a profound effect on the down-regulation of the VDR gene, which may postulate impairment of $\mathrm{Ca}$ absorption by the intestinal cells as a result of the reduced number of the receptors in these cows.

On the basis of the positive association between the increased body condition score and the occurrence of hypocalcaemia (ØSTERGAARD et al., 2003; SAED et al., 2020a), and the positive correlation between the level of $\mathrm{Ca}$ and the expression pattern of the VDR gene in the dairy cows, it was reasonable to find a significant association between the higher body condition score and the down-regulation of the VDR gene. Moreover, in dairy cows with a history of previous episodes of hypocalcemia, deficiency of the vitamin $\mathrm{D}$ as well as impaired parathyroid function leads to recurrent episodes of hypocalcemia, that may vary in clinical degree (CONSTABLE et al., 2017; SAED et al., 2020a). This is closely related to the depletion of $\mathrm{Ca}$ homeostasis resources that involve VDR gene expression to combat the condition. 


\section{Conclusion}

In conclusion, apart from renal and intestinal tissues, the expression pattern of the VDR, $1 \alpha$-OHase enzyme, and chemokine RANTES genes in the blood was greatly affected in dairy cows with hypocalcemia, indicating the need for an extra share of vitamin D to maintain the normal level of $\mathrm{Ca}$ in the blood, especially during periods of high need. Thus, the current study provides an insight into the role of vitamin D and its related enzymes in promoting the productivity of dairy cows, especially during the critical production period. Furthermore, identification of the risk factors relevant to both animals, and the serum biochemical parameters associated with decreased expression of VDR in the blood may enable practitioners and dairy cows' breeders to establish the most appropriate control measures to control the related metabolic disorders.

\section{Conflict of interest}

The authors have declared that they have no conflict of interest.

\section{Authors' contributions}

Both authors contributed equally in designing, experimentation, analysis, and manuscript preparation and finalization. Both authors finally approved the article for publication.

\section{Acknowledgements}

This study represents part of a major study entitled "Vitamin $\mathrm{D}$ receptor Gene polymorphism and its related diseases in farm animals". The authors would like to express their special gratitude and thanks to Mansoura University, Mansoura, Egypt for their support in approving this research plan.

\section{References}

AALBERTS, M., F. M. F. VAN DISSEL-EMILIANI, H. T. A. VAN TOL, M. A. TAVERNE, V. N. BREEVELDDWARKASING (2007): High iNOS mRNA and protein levels during early third trimester suggest a role for NO in prelabor cervical ripening in the bovine. Mol. Reprod. Dev. 74, 378-385.

DOI: $10.1002 / \mathrm{mrd} .20546$

ALI, M. O., M. A. EL-ADL, H. M. M. IBRAHIM, Y. Y. ELSEEDY, M. A. RIZK, S. A. EL-KHODERY (2018): Molecular characterization of the vitamin D receptor (VDR) gene in Holstein cows. Res. Vet. Sci. 118, 146-150. DOI: 10.1016/j.rvsc.2018.02.003

BECKMAN, M. J., J. A. JOHNSON, J. P. GOFF, T. A. REINHARDT, D. C. BEITZ, R. L. HORST (1995): The role of dietary calcium in the physiology of vitamin D toxicity: excess dietary vitamin D3 blunts parathyroid hormone induction of kidney 1-hydroxylase. Arch. Biochem. Biophys. 319, 535-539.

DOI: $10.1006 /$ abbi.1995.1328

BERNDT, T., S. SCHIAVI, R. KUMAR (2005): "Phosphatonins" and the regualtion of phosphorus homeostasis. Am. J. Physiol. 289, 1170-1182.

DOI: 10.1152/ajprenal.00072.2005

BERNDT, T., L. F. THOMAS, T. A. CRAIG, S. SOMMER, X. LI, E. J. BERGSTRALH, R. KUMAR (2007): Evidence for a signaling axis by which intestinal phosphate rapidly modulates renal phosphate reabsorption. Proc. Natl. Acad. Sci. USA. 104, 11085-11090.

DOI: $10.1073 /$ pnas.0704446104

CONSTABLE, P. D., K. W. HINCHCLIFF, S. H. DONE, W. GRÜNBERG (2017): Metabolic and Endocrine Diseases. In: veterinary medicine: a textbook of the diseases of cattle, horses, sheep, pigs and goats. $11^{\text {th }}$ ed. Missouri, United States: Elsevier Ltd, 1662-1757.

COOK, N., G. OETZEL, K. NORDLUND (2006): Modern techniques for monitoring high-producing cows 2. Practical applications. In Pract. 28, 598-603.

DOI: $10.1136 /$ inpract.28.10.598

DEGARIS, P. J, I. J. LEAN (2008): Milk fever in dairy cows: a review of pathophysiology and control principles. Vet. J. 176, 58-69.

DOI: $10.1016 /$ j.tvj1.2007.12.029

DELUCA, H. F. (2004): Overview of general physiologic features and functions of vitamin D. Am. J. Clin. Nutr. 80, 1689S-1696S.

DOI: $10.1093 / \mathrm{ajcn} / 80.6 .1689 \mathrm{~S}$

DEVRIES, T. J., K. A. BEAUCHEMIN, F. DOHME, K. S. SCHWARTZKOPF-GENSWEIN (2009): Repeated ruminal acidosis challenges in lactating dairy cows at high and low risk for developing acidosis: feeding, ruminating, and lying behavior. J. Dairy Sci. 92, 5067-5078.

DOI: $10.3168 /$ jds.2009-2102

GOFF, J. P. (2008): The monitoring, prevention, and treatment of milk fever and subclinical hypocalcemia in dairy cows. Vet. J. 176, 50-57.

DOI: $10.1016 /$ j.tvj1.2007.12.020

GROSS, J., H. A. VAN DORLAND, R. M. BRUCKMAIER, F. J. SCHWARZ (2011): Performance and metabolic profile of dairy cows during a lactational and deliberately induced negative energy balance with subsequent realimentation. J. Dairy Sci. 94, 1820-1830.

DOI: $10.3168 /$ jds.2010-3707

HAUSSLER, M. R., G. K. WHITFIELD, I. KANEKO, C. A. HAUSSLER, D. HSIEH, J. C. HSIEH, P. W. JURUTKA (2013): Molecular mechanisms of Vitamin D action. Calcif. Tissue Int. 92, 77-98.

DOI: $10.1007 / \mathrm{s} 00223-012-9619-0$

HAYIRLI, A. (2006): The role of exogenous insulin in the complex of hepatic lipidosis and ketosis associated with insulin resistance phenomenon in postpartum dairy cattle. Vet. Res. Commun. 30, 749-774.

DOI: $10.1007 / \mathrm{s} 11259-006-3320-6$ 
HEALY, K. D., J. L. VANHOOKE, J. M. PRAHL, H. F. DELUCA (2005): Parathyroid hormone decreases renal vitamin D receptor expression in vivo. Proc. Natl. Acad. Sci. USA. 102, 4724-4728.

DOI: 10.1073 /pnas.0501312102

HERM, G., A. S. MUSCHER-BANSE, G. BREVES, B. SCHRODER, M. R. WILKENS (2015): Renal mechanisms of calcium homeostasis in sheep and goats. Anim. Sci. J. 93, 1608-1621.

DOI: $10.2527 /$ jas.2014-8450

HERNÁNDEZ-CASTELLANO, L. E., L. L. HERNANDEZ, H. SAUERWEIN, R. M. BRUCKMAIER (2017): Endocrine and metabolic changes in transition dairy cows are affected by prepartum infusions of a serotonin precursor. J. Dairy Sci. 100, 5050-5057.

DOI: $10.3168 /$ jds.2016-12441

HORST, R., J. GOFF, T. REINHARDT (1990): Advancing age results in reduction of intestinal and bone 1,25-dihydroxyvitamin D receptor. Endocrinology 126, 1053-1057.

DOI: 10.1210 /endo-126-2-1053

HORST, R., J. GOFF, T. REINHARDT (2003): Role of vitamin $\mathrm{D}$ in calcium homeostasis and its use in prevention of bovine periparturient paresis. Acta Vet. Scand. Suppl. 97, $35-50$.

KLEIN, G. L., S. M. CASTRO, R. P. GAROFALO (2016): The calcium-sensing receptor as a mediator of inflammation. Semin. Cell. Dev. Biol. 49, 52-56.

DOI: 10.1016/j.semcdb.2015.08.006

KUREK, Ł., K. LUTNICKI, M. OLECH, P. BRODZKI, J. MARCZUK, M. GOLYNSKI (2016): Changes in selected biochemical blood parameters following various methods of postpartum hypocalcaemia prophylaxis. J. Elem. 21, 77-87.

LARSEN, T., G. MØLLER, R. BELLIO (2001): Evaluation of clinical and clinical chemical parameters in periparturient cows. J. Dairy Sci. 84, 1749-1758.

DOI: $10.3168 / j d s . S 0022-0302(01) 74610-3$

LEAN, I., P. DEGARIS, D. MCNEIL, E. BLOCK (2006): Hypocalcemia in dairy cows: meta-analysis and dietary cation anion difference theory revisited. J. Dairy Sci. 89, 669-684

DOI: $10.3168 /$ jds.S0022-0302(06)72130-0

LEAN, I. J., P. J. DEGARIS, D. M. MCNEIL, E. BLOCK (2006): Hypocalcemia in dairy cows: meta-analysis and dietary cation anion difference theory revisited. J. Dairy Sci. 89, 669-684.

DOI: $10.3168 /$ jds.S0022-0302(06)72130-0

LIAMIS, G., E. LIBEROPOULOS, F. BARKAS, M. ELISAF (2014): Diabetes mellitus and electrolyte disorders. World J. Clin. Cases 2, 488-496.

DOI: $10.12998 /$ wjcc.v2.i10.488

LIESEGANG, A., M. L. SASSI, J. RISTELI, R. EICHER, M. WANNER, J. L. RIOND (1998): Comparison of bone resorption markers during hypocalcemia in dairy cows. J. Dairy Sci. 81, 2614-2622.

DOI: $10.3168 /$ jds.S0022-0302(98)75819-9
LIESEGANG, A., K. RINER, A. BOOS (2007): Effects of gestation and lactation on vitamin $\mathrm{D}$ receptor amounts in goats and sheep. Domest. Anim. Endocrinol. 33, 190-202. DOI: 10.1016/j.domaniend.2006.05.008

LIVAK, K. J., T. D. SCHMITTGEN (2001): Analysis of relative gene expression data using real-time quantitative PCR and the 2- $\triangle \Delta C T$ method. Methods 25, 402-408.

DOI: $10.1006 /$ meth.2001.1262

MULLIGAN, F., L. O'GRADY, D. RICE, M. DOHERTY (2006): A herd health approach to dairy cow nutrition and production diseases of the transition cow. Anim. Reprod. Sci. 96, 331-353.

DOI: $10.1016 /$ j.anireprosci.2006.08.011

NAVEH-MANY, T., R. MARX, E. KESHET, J. PIKE, J. SILVER (1990): Regulation of 1,25-dihydroxyvitamin D3 receptor gene expression by 1,25-dihydroxyvitamin D3 in the parathyroid in vivo. J. Clin. Investig. 86, 1968-1975.

DOI: $10.1172 /$ JCI114931

NELSON, C. D., T. A. REINHARDT, T. C. THACKER, D. C. BEITZ, J. D. LIPPOLIS (2010): Modulation of the bovine innate immune response by production of $1 \alpha, 25$ dihydroxyvitamin D3 in bovine monocytes. J. Dairy Sci. 93, 1041-1049.

DOI: $10.3168 /$ jds.2009-2663

ØSTERGAARD, S., J. T. SØRENSEN, H. HOUE (2003): A stochastic model simulating milk fever in a dairy herd. Prev. Vet. Med. 58, 125-143.

DOI: 10.1016/S0167-5877(03)00049-7

ÖZÇELIK, R., R. M. BRUCKMAIER, L. E. HERNÁNDEZCASTELLANO (2017): Prepartum daylight exposure increases serum calcium concentrations in dairy cows at the onset of lactation. Anim. Sci. J. 95, 4440-4447.

DOI: $10.2527 /$ jas 2017.1834

REINHARDT, T. A., J. D. LIPPOLIS, B. J. MCCLUSKEY, J. P. GOFF, R. L. HORST (2011): Prevalence of subclinical hypocalcemia in dairy herds. Vet. J. 188, 122-124.

DOI: $10.1016 /$ j.tvj1.2010.03.025

RÉRAT, M., A. PHILIPP, H. D. HESS, A. LIESEGANG (2009): Effect of different potassium levels in hay on acidbase status and mineral balance in periparturient dairy cows. J. Dairy Sci. 92, 6123-6133.

DOI: $10.3168 /$ jds.2009-2449

ROCHE, J., D. BERRY (2006): Periparturient climatic, animal, and management factors influencing the incidence of milk fever in grazing systems. J. Dairy Sci. 89, 2775-2783. DOI: $10.3168 /$ jds.S0022-0302(06)72354-2

RORSMAN, P., M. BRAUN, Q. ZHANG (2012): Regulation of calcium in pancreatic $\alpha$ - and $\beta$-cells in health and disease. Cell Calcium 51, 300-308.

DOI: $10.1016 /$ j.ceca.2011.11.006

SABORÍO-MONTERO, A., B. VARGAS-LEITÓN, J. ROMERO-ZÚÑIGA, J. SÁNCHEZ (2017): Risk factors associated with milk fever occurrence in grazing dairy cattle. J. Dairy Sci. 100, 9715-9722. DOI: $10.3168 /$ jds.2017-13065 
SAED, H. A. R., H. M. M. IBRAHIM, S. A. EL-KHODERY, M. A. YOUSSEF (2020): Relationship between expression pattern of vitamin D receptor, 1 alpha-hydroxylase enzyme, and chemokine RANTES genes and selected serum parameters during transition period in Holstein dairy cows. Vet. Rec. Open 7, e000339.

DOI: 10.1136/vetreco-2019-000339

SAED, H. A. R., H. M. M. IBRAHIM, S. A. EL-KHODERY, M. A. YOUSSEF (2020a). Prevalence and potential risk factors of hypocalcaemia in dairy cows during transition period at Northern Egypt. Mansoura Vet. Med. J. 21, 21-30. DOI: $10.35943 / \mathrm{mvmj} .2020 .21 .104$

SKRZYPCZAK, W., A. KURPINSKA, Ł. STANSKI, A. JAROSZ (2014): Sodium, potassium and chloride homeostasis in cows during pregnancy and fist months of lactation. Acta Biol. Cracov. Ser. Zool. 55, 58-64.

SUNG, C. C., M. T. LIAO, K. C. LU, C. C. WU (2012): Role of vitamin D in insulin resistance. J. Biomed. Biotechnol. 2012, 634195.

DOI: $10.1155 / 2012 / 634195$

TADESSE, E., L. BELETE (2015): An overview on milk fever in dairy cattle in and around West Shoa. World J. Biol. Med. Sci. 2, 115-125.
UDENSI, U. K., P. B. TCHOUNWOU (2017): Potassium homeostasis, oxidative stress, and human disease. Int. J. Clin. Exp. Physiol. 4, 111-122.

DOI: 10.4103/ijcep.ijcep_43_17

WILHELM, A. L., M. G. MAQUIVAR, S. BAS, T. A. BRICK, W. P. WEISS, H. BOTHE, J. S. VELEZ, G. M. SCHUENEMANN (2017): Effect of serum calcium status at calving on survival, health, and performance of postpartum Holstein cows and calves under certified organic management. J. Dairy Sci. 100, 3059-3067.

DOI: $10.3168 /$ jds.2016-11743

WILKENS, M. R., A. S. MUSCHER-BANSE (2020): Review: Regulation of gastrointestinal and renal transport of calcium and phosphorus in ruminants. Animal 14, s29-s43. DOI: $10.1017 / \mathrm{S} 1751731119003197$

WILKENS, M. R., K. ELFERS, M. SCHMICKE, G. BREVES, A. S. MUSCHER-BANSE (2018): Dietary nitrogen and calcium modulate CYP27B1 expression in young goats. Domest. Anim. Endocrinol. 64, 70-76.

DOI: 10.1016/j.domaniend.2018.03.005

WRIGHT, R., J. BLAIR-WEST, J. NELSON, G. TREGEAR (1984): Handling of phosphate by a parotid gland (ovine). Am. J. Physiol. 246, F916-F926.

DOI: 10.1152/ajprenal.1984.246.6.F916

Received: 30 November 2020

Accepted: 8 March 2021

\section{SAED, H. A. R., H. M. M. IBRAHIM: Signalizacija gena za receptor vitamina D, enzim 1 alfa-hidroksilazu i RANTES u mliječnih krava s hipokalcemijom. Vet. arhiv 91, 575-588, 2021. \\ SAŽETAK}

Cilj ovog istraživanja bio je nadzor genskog signala za receptor vitamina D (VDR), enzim 1-alfa-hidroksilazu (1 $\alpha$-OHase) i kemokin (Regulated on Activation Normal T-cell Expressed and Secreted - RANTES) u mliječnih krava s hipokalcemijom. Uzorci za biokemijske i molekularne analize prikupljeni su od 120 mliječnih krava (20 krava po stadu), tijekom prijelaznog razdoblja. U krava s subkliničkom i kliničkom hipokalcemijom utvrđena je znakovita (P $<0,05)$ podregulacija gena VDR i RANTES, te znakovita $(\mathrm{P}<0,05)$ nadregulacija enzima 1 - $\alpha$-Ohaza. Nadalje, $\mathrm{u}$ tih životinja došlo je do znakovitog $(\mathrm{P}<0,05)$ povećanja razina glukoze, paratireoidnog hormona $(\mathrm{PTH})$, natrija $(\mathrm{Na})$ i klorida $(\mathrm{Cl})$, te znakovitog $(\mathrm{P}<0,05)$ smanjenja razina fosfora $(\mathrm{P})$ i kalija $(\mathrm{K})$. Uvažavajući različite osobine životinja utvrđena je znakovita povezanost između izražajnosti VDR gena i pasmine krava, dobi krava, redoslijeda teljenja, ocjene tjelesne kondicije te prethodnih poremećaja u prijelaznom razdoblju. Povećanje, s jedne strane ekspresije za enzim $1 \alpha$-OHase i s druge strane razine PTH, glukoze, $\mathrm{Na} \mathrm{i} \mathrm{Cl}$ u serumu, dovelo je do znakovitog rizika za smanjenu ekspresiju VDR gena. Isto tako, smanjenje ekspresije gena RANTES i razine kalcija (Ca) i fosfora (P) u serumu bili su značajni čimbenici rizika za smanjenu ekspresiju gena VDR. Ovo je istraživanje pokazalo da je na ekspresiju gena VDR, $1 \alpha$-Ohaza i RANTES u krvi mliječnih krava uvelike utjecala hipokalcemija, što upućuje na potrebu dodatne doze vitamina $\mathrm{D}$ kako bi se održala normalna razina $\mathrm{Ca}$ u krvi, osobito u zahtjevnim razdobljima visoke proizvodnje. Stoga ova studija daje uvid u ulogu vitamina $\mathrm{D}$ i s njim povezanih enzima u poboljšanju produktivnosti mliječnih krava, posebno u kritičnim razdobljima proizvodnje.

Ključne riječi: vitamin D receptor; 1- $\alpha$ hidroksilaza enzim; RANTES; hipokalcemija; mliječne krave 